\title{
GLOBAL ISSUES OF ENVIRONMENTAL LAW ENFORCEMENT IMPACTS ON SUSTAINABLE DEVELOPMENT
}

\author{
Sopian $^{\left.a^{*}\right)}$, Sri Rahayu Pudjiastuti ${ }^{a}$ \\ a) STKIP Arrahmaniyah, Depok, Indonesia \\ ${ }^{*}$ Corresponding Author: sopian@stkip-arrahmaniyah.ac.id
}

Article history: received 09 January 2021; revised 13 February 2021; accepted 26 February 2021

\begin{abstract}
The global environmental crisis is caused by wrong and failed policies, low political commitment, deviant behavior from state actors ranging from trans-national corporations, consumerism and individualism culture, which ultimately harms the environment. The purpose of this research is to analyze environmental law, the form and importance of law enforcement in realizing sustainable development. The method used in this paper is to use a normative juridical approach. The results of the research show that currently environmental law is still weak in overcoming various environmental problems that occur. The cause of not optimal environmental law is the lack of a firm and real form of law enforcement. Therefore, law enforcement must be enforced for the realization of sustainable development
\end{abstract}

Keywords: global issues; law enforcement; environment

\section{INTRODUCTION}

In the era of globalization, environmental issues have become a global discourse that has received serious attention from the public. Problems The risk of environmental problems is one of the causes of the interaction between environmental elements. Pollution and environmental damage in Indonesia are quite serious problems. Environmental problems are still a big responsibility because they involve the quality of life in the future. Exploitation of natural resources and the environment has led to the deterioration of the quality of the environment, especially natural resources. Rampant natural damage, such as marine ecosystems, destruction of forests as the world's lungs, floods that occur everywhere, landslides, and many other problems. [1]

Global environmental crises currently occurring include damage (forest, land, ozone layer), pollution (water, land, air, sea), extinction of energy and mineral resources, extinction of biodiversity, and others. Where the global environmental crisis is a very serious and real threat to human life. The root causes of the global environmental crisis include; (1) wrong perspective, between the relationship between humans and the relationship between humans and nature. Human nature that is greedy, greedy, consumption patterns, exploitative and irresponsible is one of the problems that exist. (2) The wrong development paradigm, where sustainable development is only a jargon, which in fact the development that occurs at the expense of the environment. (3) Unethical behavior, for example corruption, collusion and nepotism, which results in permits to exploit without paying attention to the environment. [2]

Errors regarding environmental problems that occur due to several factors, such as economic problems, individual or group interests, lifestyle, and more importantly weaknesses in the system of applicable laws and regulations and weak systems of supervision of various environmental management and protection. Law is a way of reflecting on a value system that is believed by the community as an institution in everyday life including personal, social, national and state life that must be upheld [3]. Therefore, it is necessary to enforce the law in order to protect the environment. Law enforcement can be used as a rule to overcome environmental problems based on Law Number 32 of 2009 concerning Environmental Management and Protection.

The existence of law enforcement is carried out so that activities in order to carry out various legal provisions, both preventive and prosecutorial in nature, must cover all aspects of activities that are both technical and administrative, where this can be carried out by legal officials and the government in accordance with the rules contained in the law. the current law. Research conducted by Anggrasena [4] states that if law enforcement can be carried out properly, it will create the expected conditions so that development in all sectors can be planned and carried out. Law enforcement in environmental issues has been regulated in Law Number 32 of 2009 contained in articles 15 to 97 which describes criminal sanctions against environmental crimes. The articles contained in Law Number 32 Year 2009 can be used as a guideline to pay more attention to the importance of law enforcement in various environmental problems.

In the environmental law enforcement system in Indonesia, the laws and regulations on the environment are adequate, however law enforcement in Indonesia by agencies/agencies and law enforcement officials has not been running professionally and optimally. In order for environmental law enforcement in Indonesia to be optimal, it is hoped that law enforcement agencies/agencies and 
officials of the law will have the moral capability and be professional in solving environmental problems, in accordance with laws and regulations that are directly related to these environmental problems.

\section{RESEARCH METHODS}

This study uses a normative juridical approach. The research was conducted by focusing on the general principles that underlie the manifestation of the symptom units that exist in social life. The discussion in this study was carried out through descriptive analysis supported by secondary data and literature studies, namely data derived from laws, results of legal research, law enforcement in environmental problems and sustainable development. [5] Data collection techniques are carried out through literature studies to collect literature and information in accordance with various legal materials through the results of a review of library sources in the form of documents, books, journals, newspapers related to legal materials, because they depart from the obscurity of law enforcement on environmental problems. by using a descriptive approach through statutory regulations, legal concepts, and comparative laws. Data analysis was carried out by means of qualitative juridical analysis and the results of the analysis were presented in descriptive form. Descriptive method [6] is used to describe environmental issues that occur in the era of globalization. Based on this analysis, deductive conclusions are drawn

\section{RESULTS AND DISCUSSION}

\section{Globalization Issues}

Globalization is a cultural process, in which there is a tendency for regions in the world to become one in a sociopolitical-legal format [7]. In globalization, the characteristics of the relationship between the inhabitants of the earth have transcended conventional boundaries such as nation and state. Thus, in the process of globalization, the world is experiencing a process of global reconstruction which results in the laws of the nations of the world experiencing internationalization as part of the process.

Understanding the multilateral negotiation process in the environmental sector, whether in the context of developing international cooperation or establishing an international environmental regime, is essentially understanding a global political process that is very complex and dynamic. That said, because the character of the environmental issue itself tends to be very multimensional, high technicalities and scientific. Meanwhile, the multilateral negotiation process at the global level involved many actors (State and non-state) with very diverse perceptions and aspirations of interests. An understanding of the dynamics that develops in a broader context is needed, namely regarding the substance of the issues being negotiated and how actors set an issue to be a priority on the global environmental agenda which must receive attention in the formulation and implementation of policies at the international (regional-multilateral) and national level respectively each country. Although each actor plays different roles and functions, all of them contribute significantly in influencing the dynamics of global environmental politics and the formation of international environmental regimes, both during the negotiation process, implementation and enforcement of the agreements that have been reached.

The political process of the globalization of environmental issues was marked by the holding of two major events by the United Nations, namely the UN Conference on the Human Environment in 1972 in Stockholm Sweden, otherwise known as the Stockholm conference, and the UN Conference on Environment and Development in 1992 in Rio de Jenerio , Brazil or what is often referred to as the Rio Conference or Earth Summit. [8] Agenda 21 and the UN Commission on Sustainable Development are the focal points of the Rio conference which try to guard the commitment and consistency of leaders and the world community to implement their agreement on sustainable development. Sustainable Development has a positive potential for the development of human rights at the national and international levels, by incorporating rights to a healthy environment for everyone.

The results of the multilateral conference contained a pessimistic view that expressed the protection of the global environment without sacrificing the interests of economic development; but on the contrary, there is not a bit of pessimism and sharp criticism of what has been attempted through conference to conference. To be sure, it appears that political will is unable to keep pace with the dynamic development of environmental problems, both in terms of quantity (increasingly diverse) and quality (decreasing). There are at least three agendas in global environmental politics that are interrelated, namely (1) strengthening regime effectiveness, (2) global environmental governance, and (3) normative frameworks and principles.

Since the early 1970s, global environmental governance has been marked by a flood of formal and informal institutions that encourage or facilitate multilateral negotiations, standardization and management of environmental change that are global and cross-border. The context of the discourse to strengthen global environmental governance is essentially the process of implementing sustainable development with the integrity of its three pillars, namely environmental, economic and social. The urge to strengthen global environmental governance contextually cannot be separated from the strengthening of the globalization paradigm with trade and investment liberalization as the mean stream. Although it is recognized that the Earth Summit in Rio de Jeneiro 1992 has provided a strong political and legal basis for the resolution of the current global environmental crisis, the paradigm of globalization with its institutionalized free market in the World Trade Organization (WTO) is felt to be a stumbling block to the process of implementing Sustainable Development [9]. This global environmental governance agenda is essentially centered on the issue of institutional reform from a number of important institutions related to 
environmental management and normative frameworks and principles related to legal and practical guidelines for actors who are directly or indirectly involved in the process of producing, implementing and enforcing results. - the results of joint decisions on how best to respond to this problem of global environmental damage.

\section{Environmental law}

The reciprocal relationship between humans and their environment requires a set of rules that regulate human attitudes and behavior towards their environment, namely an environmental law. According to Drupsteen, environmental law (milieurecht) in its broadest sense. Moenadjat Danusaputro divides environmental law into two types, namely modern environmental law which is oriented to the use of the environment (Use-Oriented Law). Modern environmental laws are rules and norms to regulate human behavior with the aim of protecting the environment from damage and deterioration of its quality to ensure its sustainability so that it is continuously used by current and future generations. Meanwhile, classical environmental law stipulates provisions and norms with the sole purpose of ensuring the use and exploitation of environmental resources with various human intellect and intelligence in order to achieve the maximum possible result, and in the shortest possible timeframe. Environmental law is also often considered as a juridical instrument for any environmental management and protection [10]. Therefore, in every implementation of environmental law, we will always pay attention to all general principles of good governance. The existence of these principles will provide an objective so that in every implementation of policies and regulations in effect will not deviate from the objectives of environmental management and protection that have been set for the common interest so that everyone has the right to experience a beneficial and healthy environment.

In environmental law, it will always be related to environmental problems such as cases of forest fires, species extinction, deforestation, climate change, etc [11]. In enforcing the law on the environment, there are rules to regulate the environment or the environment, which includes all aspects that aim to regulate all human actions in order to protect the environment from various damages and pollution in order to achieve the welfare and sustainability of future generations.

According to Koesnadi Hardjosoemantri [12], that environmental law in Indonesia includes the following aspects; (1) Environmental Management Law, (2) Environmental Protection Law, (3) Environmental Health Law, (4) Environmental Pollution Law, (5) Transnational/ International Environmental Law. (6) Environmental Disputes Law.

Laws and regulations governing the environment and its scope, among others; (1) Law Number 32 Year 2007 concerning the protection and management of the environment, (2) Law Number 5 Year 1983 concerning the Exclusive Economic Zone, (3) Law Number 5 Year 1990 concerning the conservation of living natural resources and their ecosystems , (4) Law number 5 of 1992 concerning cultural heritage objects, (5) Law number 41 of 1999 concerning forestry, (6) Government regulation number 20 of 1990 concerning water pollution control, (7) Government regulation number 221082 concerning water use systems, (8) Government regulation number 29 of 1986 concerning environmental impact analysis, (9) Government regulation number 7 of 1990 concerning the right to control industrial plantations, (10) Government regulation in lieu of law number 1 year 2004, LNRI 2004 number 29 Government regulation in lieu of Law number 41 of 1999 concerning forestry, (11) Decree of the Minister of State for Population and Environment (KLH) number Kep-02/MENKLH/1988 concerning guidelines for setting environmental quality standards.

Legal provisions relating to the prevention and overcoming of environmental pollution, in addition to Law No. 4 of 1982 concerning Basic Provisions for the Management of the Living Environment, including; (1) Law for Preventing and Combating Pollution in the Mining Sector (2) Law for Preventing and Combating Environmental Pollution in the Industrial Sector (3) Law for Preventing and Combating Environmental Pollution in the Irrigation Sector (4) Law for Preventing and Combating Illegal Logging/Illegal Logging.

Policies for the management and utilization of natural resources are still overlapping, inconsistent and out of sync at various levels, thus opening opportunities for investors and unscrupulous officials to practice corruption, and weak law enforcement and national management systems in the management and utilization of natural resources [13].

\section{The environmental law enforcement system}

The environmental law enforcement system has been regulated by all forms of violations and crimes, for perpetrators, whether committed by individuals or bodies with preventive and repressive measures. Enforcement of environmental laws in the context of controlling environmental pollution can be divided into three aspects; (1) Enforcement of administrative environmental laws by government officials, (2) enforcement of criminal environmental laws through judicial juridical procedures, and (3) enforcement of civil environmental laws by litigation and non-litigation.

1. Application of Administrative Law in Enforcement of Environmental Law in Indonesia.

Administrative environmental law enforcement aims to stop environmental pollution directly at the source in accordance with the principles of supervision and application of administrative sanctions. Periodic supervision is carried out on activities that have an environmental permit as an effort to monitor the arrangement of licensing requirements by the agency authorized to grant environmental permits.

In Law number 32 of 2009 concerning Environmental Protection and Management, administrative sanctions are regulated in Article 71. Article 71 paragraph (1) states: The Governor/Head of TK I Region has the authority to enforce 
government coercion against those in charge of businesses and/or activities to prevent or ending the occurrence of violations and overcoming the consequences caused by a violation, carrying out rescue, mitigating and/or restoring the costs of the person in charge of the business and/or activity, unless otherwise stipulated by law".

There is no comprehensive regulation in controlling environmental pollution. This fact confirms the view that the enforcement of administrative environment law in the context of controlling environmental pollution through juridical means that are preventive in nature has not run optimally. Mastery of environmental pollution control methods and techniques among the administrative environment law enforcement officers is still limited. There are differences or even misunderstandings about the substance and mechanism of monitoring the arrangement of environmental licensing requirements. The application of administrative sanctions is a continuation consequence of the administrative sanctions supervision action has an instrumental function. Control of prohibited acts and consists of (1) government coercion or coercion, (2) forced money, (3) closure of business premises, (4) cessation of company machinery activities, (5) revocation of permits. Through a process; reprimands, government coercion, closure and forced money [14].

The main legal basis for the application of administrative sanctions in the field of environmental pollution control is contained in Articles 76-83 of the PPLH Law which regulates four types of administrative sanctions: written warning, government coercion, suspension of environmental permits, or revocation of environmental permits against business entities that violate emission quality standards and requirements. other environment. The stipulation of this sanction must not be less than the economic value that the offender has enjoyed as long as he does not comply with the environmental permit requirements[15]. There are several variants of administrative sanctions imposed by the agency authorized to issue environmental permits, namely; admonition, warning, sealing, summons etc. This shows that the agency authorized to issue environmental permits has little control over the laws and regulations governing the types of administrative sanctions. The implementation of administrative work has not been linked to violations of environmental licensing requirements and has put more emphasis on the implementation of Amdal.

This study describes the reality of how limited the means of enforcing the law for the administrative environment are, even if there are some formulations that are wrong and the application is ambiguous. This fact proves that the enforcement of administrative environmental laws is not yet effective and efficient as a legal instrument for controlling environmental pollution to guarantee statutory regulations (environmental pollution control). The sanction of license revocation is used as the last alternative in order to encourage the arrangement of licensing requirements or statutory regulations after going through the stages of imposition of fines and criminal sanctions.
2. Application of Civil Law in Enforcement of Environmental Law in Indonesia

In the handling of civil environmental cases, legal problems are often found that are not covered by existing laws and regulations. This is because in the case of evidence of pollution it is characterized by its unique characteristics, namely; (1) the cause does not have to come from a single source, but can be from various sources (multisources). (2) Involving other disciplines and demanding the involvement of experts outside the law as expert witnesses.

In Indonesia, environmental dispute resolution is regulated in Chapter XIII of the PPLH Law, which is divided into out-of-court environmental dispute resolution and environmental dispute resolution through courts. Environmental lawsuits can only be filed after an out-ofcourt environmental dispute resolution mechanism cannot be reached. Enforcement of environmental law through civil law channels in Indonesia is less favorable because of the protracted process in court because almost all civil cases are sought in the highest court for cassation and even proceed to a review. After a decision is made, it is often difficult to enforce it. According to the provisions of Article 84 of the UUPLH, environmental (civil) disputes can be pursued through the court or outside the court based on the voluntary choice of the parties concerned. If the selected out-of-court effort is unsuccessful, then one or the parties may pursue a court route. Article 88 UUPPLH explains that responsibility or strict liability is an element of error that does not have to be proven from the plaintiff on the basis of compensation payments. The provisions of this paragraph constitute a lex specialist in lawsuits concerning acts of violation of the law in general. UUPPLH explains that, representatives who have the authority to file claims for compensation for environmental pollution/destruction are the government and local governments, communities, and environmental organizations.

There are two kinds of ways that can be taken to resolve environmental disputes. First, dispute resolution through an out-of-court dispute resolution mechanism. Second, dispute resolution through courts. Each party is free to decide whether he or she will choose an out of or through settlement. If the disputing party determines the settlement of the dispute outside or through the court, it cannot take a settlement route through the court before a statement is made if the mechanism is not successful by one of the disputing parties. Out of court dispute resolution cannot be used to resolve environmental crimes. In civil law, there are not always environmental disputes between individuals, but also on behalf of groups of people with the same interests through group action. In civil law, environmental issues do not rule out filing a civil lawsuit. In Article 84 of Law Number 32 Year 2009 concerning Environmental Protection and Management, it is specifically regulated regarding the settlement of environmental disputes.

\section{Application of Criminal Law in Enforcement of Environmental Law in Indonesia}


The enactment of criminal law still takes into account the principle of subsidiarity, namely that criminal law should be utilized if sanctions in other areas of law, such as administrative sanctions and civil sanctions, and alternative environmental dispute resolution are ineffective and/or the level of misbehavior is relatively severe and/or the result of the action is relatively large. and/or the level of error by the perpetrator is relatively heavy and/or the result of his actions is relatively large and/or his actions cause public unrest. Investigation to determine whether an act of polluting or damaging the environment can be punished, requires the formulation of "environmental offense (environmental pollution)" based on the "legality principle" contained in Article 1 paragraph (1) of the Criminal Code (KUHP): "nullum delictum nulla poena sine praevia lege poenali ". UUPPLH regulates criminal provisions in Articles 97-120, however, the UUPLH does not formulate the definition of environmental offense. The problem of the formulation of environmental pollution offenses can be resolved by understanding the juridical definition of environmental pollution and the formulation of criminal sanctions. Based on Article 1 number 14 UUPPLH and Article 97-120 UUPPLH, the definition of environmental pollution offense can be formulated: is "an act committed on purpose or due to negligence which results in the entry or inclusion of living things, substances, energy, and/or other components in the environment. living by human activities so as to exceed the stipulated environmental quality standards "

In short, it can be said that the environmental offense of environmental pollution is "an act that is done intentionally or because of negligence which causes environmental pollution". Referring to Article 97120 of the PPLH Law, it is known that: "the subject of environmental pollution offense" who bears criminal responsibility is "everyone" (both individuals and legal entities). The formulation of the environmental offense has two basic elements: "the action and the resulting effect". These two elements can be used as guidelines for qualifying environmental offenses against environmental pollution as "material offenses" or "formal offenses". Material offenses are oriented towards constitutive consequences, while formal offenses emphasize their actions" [16]. Determining environmental offenses as material offenses or formal offenses has legal consequences related to the ability to "present evidence (proof)" and "determine the causal relationship (causality) between acts of pollution and environmental pollution. In the formulation of a material offense, proof is required that is more complicated than the formulation of a formal offense which does not require proof of the consequences of an act of polluting. Formal offense does not prove the effect but only proves the occurrence of an "act" (doing or not doing). The substance of evidence is oriented towards the presentation and evaluation of facts to underlie the construction of a judge's decision convincingly. The truth of facts must be found in the criminal justice mechanism so that judges can choose the right law ("inabstracto") to make decisions ("in concreto") that are "executable". Law No.35 of 1999 concerning amendments to
Law No.14 of 1970 concerning Basic Provisions of Judicial Power (Law on Judicial Power) and Law No. 8 of 1981 concerning Criminal Procedure Law (KUHAP). Types of evidence that are valid according to Article 6 paragraph (2) of the Law on Judicial Power and Article 183 KUHAP are regulated in Article 184 of the Criminal Procedure Code, namely: witness statements, expert statements, letters, instructions, and statements of defendants. The role of investigators in environmental offenses is very important, because they are tasked with collecting facts and evidence which is often scientific, especially for environmental pollution in cities that occurs cumulatively. The notion of the presumption of causal relationships is a creative finding to solve the problem of proof and causality in environmental offenses (environmental pollution) which pose an immediate danger to life and public health. [14] The complexity of proof and causality by establishing the principle of "presumption of causation" is a legal finding that deserves to be considered in the framework of drafting the KUHP-RUU KUHAP Bill which has been prepared by the Ministry of Justice and Human Rights. Criminalization of environmental pollution is a reaction to environmental offenses which philosophically aims to provide legal protection for the quality of the environment for the community. Criminal liability for environmental offenses can be borne by individuals or legal entities, criminal sanctions which are usually individual (personality) in the end can also be applied to legal entities that commit environmental pollution offenses.

\section{Environmental Law Enforcement Issues Influence on Sustainable Development Paradigm.}

The term sustainable development has begun to be known at the general session of the United Nations (UN) in formulating various regulations. Sustainable development is a global scale in a long-term project [17]. Meanwhile in Indonesia, sustainable development has been regulated in the Presidential Regulation of the Republic of Indonesia Number 59 of 2017 concerning the implementation of achieving the goals of sustainable development [18]. In setting the goals of the Sustainable Development Agenda as this is stated in a document, namely Transforming Our World: The 2030 Agenda for Sustainable Development (SDGs) as one of the agreements carried out jointly on global development which contains 17 target objectives.

One of the targets of the 17 objectives is the management and protection of the environment. The protection of the environment can be carried out by making various efforts to restore the environment, and promote the sustainable use of environmental ecosystems, protection of forest management, combating any degradation that occurs, stopping the degradation of a land, planting trees regularly, and stop various activities that are detrimental to the loss of biodiversity that exist in various regions [19].

The concept of law and sustainable development is currently one of the most important issues in the 21 st century and is the most important issue that never stops to be discussed. The two are inseparable, because they need each 
other and are binding. Legal and sustainable development aims to provide a better quality of life so that humans can meet the basic needs of their previous lives to support various lives at a higher level [20].

Law has developed and expanded rapidly where the law is not only focused on protecting, controlling, and ensuring society as an agent of stability, but now law is more prominent for sustainable development, where the law can be used as an agent of changes in any changes that apply in society around. Law and management and protection of the environment as a forum for fulfilling each other's interests where the two are mutually binding and have a very close relationship [21].

The link between environmental law enforcement issues cannot be separated from the problem of the sustainable development paradigm. The sustainable development paradigm approach is not in line with the environmental law enforcement paradigm. The sustainable development approach aims to reach a consensus covering the needs of all countries, building partnerships where the strong will help the weak, striving for the unification of concerns for the environment and development, intervening with the State and the international community in the public interest in order to achieve greater social justice, and strive to achieve sustainable development [22].

The estuary of all environmental problems is development carried out without considering the environmental balance factor which in turn will cause environmental damage and pollution. In enforcing the law itself, it needs to be supported by several factors, namely legal means, law enforcement officers, facilities and facilities, licensing, Amdal system, public legal awareness of the environment.

\section{CONCLUSION}

Various environmental problems, both damage and pollution that occur on the one hand, are considered by some to be a natural disaster (act of God/force major). In fact, in realistic conditions this is an environmental and humanitarian disaster, the cause of which is due to the impact of a policy and the lack of seriousness of public authorities in prioritizing environmental interests in the state policy agenda. The number of alternative mechanisms for environmental law enforcement, both administratively, criminal and civil, have not been able to guarantee the reduction of environmental problems. In the context of criminal law enforcement, it has not been able to have a significant effect on environmental protection. Regarding environmental crime, it is clear that legal steps are needed to be handled professionally by police officers, PPNS, prosecutors and environmentally certified judges. The spirit of integration must be encouraged in order to develop integrated law enforcement against environmental crimes. This integration is important in order to open up space for access to justice for the people that can be properly administered in the context of good environmental enforcement based on the principles of good environmental governance.

Placing Indonesia's environmental problems as a world problem, because of a number of Indonesian identities that are important in global environmental issues; geographic, demographic, socioeconomic. Indonesia must be able to convince the world public, especially developed countries, that Indonesia is "the first dominos" for a number of environmental issues that are vital to the interests of Indonesia's sustainable development, by building an image as a country that is concerned with environmental problems through policies pro-environmental policies.

\section{REFERENCES}

[1] Badan Pusat Statistik, Statistik Lingkungan Hidup Indonesia, Badan Pusat Statistik, Indonesia:2018, h.3.

[2] Pudjiastuti, Sri Rahayu, Etika Lingkungan, Depok: Gemala, 2020.

[3] Zainal Arifin Hoesein, "Pembentukan Hukum Dalam Perspektif Pembaruan Hukum (Law Making on the perspective of Legal Reformation)", Jurnal Rechts Vinding Media Pembinaan Hukum Nasional, Vol.1, No.3, 2012.h.308.

[4] Bima Anggrasena, Strategi Penegakan Hukum Dalam Rangka Meningkatkan Keselamatan Lalu Lintas Dan Mewujudkan Masyarakat Patuh Hukum. Tesis, Universitas Diponegoro, 2010.h.17.

[5] Sri Rahayu Pudjiastuti, Sri Rumiati. Development of the PKn Learning Attitude Assesment Model in Foreign Political Culture and Results of PKn Learning from Students of Depok City Vocational School (SMK Semesta Cimanggis). JhSS Journal of Humanities and Social Studies, e-ISSN:2598-120X | p-ISSN:2598-117X. Sinta-3. Vol. 3, No.1. 2019.

[6] Pudjiastuti, Sri Rahayu, (2019). Penelitian Pendidikan. Media Akademi, Yogyakarta.

[7] Heru Nugroho, "Agenda Aksi Atas Problema Globalisasi Ekonomi”, dalam buku Problema Globalisasi Perspektif Sosiologi, Hukum, Ekonomi dan Agama, Editor Khudzaifah Dimiyati \& Kelik Wardiono, Muhamadiyah University Press, Surakarta, 2000.h.44.

[8] Nurul Isnaeni \& Broto Wardoyo, Isu Lingkungan Hidup Global:Tantangan Kebijakan Luar Negeri dan Negosiasi Multilateral, GLOBAL. Vol.9 No.2 Desember 2007-Mei 2008.

[9] H.Jhamtani, Pembangunan Berkelanjutan di Tengah Globalissasi, GLOBAL Vol.5 No.1 November 2002.Page 5.

[10] Ratnasari Fajariya Abidin, "Penegakan Hukum Lingkungan Hidup dalam Perspektif Filsafat Ilmu Hukum", Jurnal Hukum Bisnis Islam, Vol.6, No.2, 2015.h.70.

[11] Elizabeth Fisher, "Environmental Law-A Very Short Introduction", Environmental Law Review, Vol.20, No.1. 2018.h.65. 
[12] Hardjasoemantri, Kusnadi, Hukum Tata Lingkungan, Edisi Kelima, Cetakan Kesepuluh, Gajah Mada University Press, Yogyakarta,1993.

[13] Pudjiastuti, Sri Rahayu. Utilization of Forest Natural Resource Potentials, Especially Wood, to Realize Independence of Regional Development, Jour of Adv Reserarch in Dynamical \& Control System, Vol.12, Issue-02, 2020.2 DOI: 10.5373/JARDCS/V1212/S20201212,

Accepted:April 20, 2020.

[14] Siti Sundari Rangkuti et.al. Implementasi UUPLH Tentang Pengawasan dan Sanksi Administrasi Dalam Pengelolaan Lingkungan di Daerah, Proyek Pendayagunaan Sistem dan Pelaksanaan Pengawasan Kantor Menteri Negara Lingkungan Hidup dan PPLH Lembaga Penelitian Universitas Airlangga; JakartaSurabaya, 2000.h.50-69.

[15] Takdir Rahmadi, Pengaturan Hukum Tentang Pengelolaan Bahan Berbahaya dan Beracun di Indonesia, Disertasi:Program Pasca Sarjana Universitas Airlangga Surabaya, 1998.h.282-283.

[16] Schamelster, M. Kelzer dan EPH. Sutarlus, Hukum Pidana, Editor J.E. Schetapy, Liberty, Yogyakarta

[17] Ksenia Ichenko \& Anastasia Lisogor, "Sustainable Development Modeling for Municipalities", Theoretical and Empirical Researches in Urban Management, Vol.11, No.1, 2016. H.77-85.

[18] Peraturan Presiden Republik Indonesia Nomor 59 Tahun 2017 Tentang Pelaksanaan Pencapaian Tujuan Pembangunan Berkelanjutan.

[19] Ahmad Fauzi \& Alex Oktovianus, "Pengukuran Pembangunan Berkelanjutan di Indonesia”, MIMBAR, Vol.30, No.1, 2014.h.46.

[20] Mira Rosana, "Kebijakan Pembangunan Berkelanjutan Yang Berwawasan Lingkungan di Indonesia" Jurnal KELOLA: Jurnal Ilmu Sosial, Vol.1, No.1. 2018.h.152.

[21] Astrid Epiney, "EU Environmental law: Sources, instrument, reflections on major developments over the last 20 Years", EU Environmental Law: Sources Instruments and Enforcement, Vol.20, No.3, 2013.h.404.

[22] Martin Khor, Globalisasi \& Krisis Pembangunan Berkelanjutan, Seri Kajian Globalisasi, Cinderalas Pustaka Rakyat Cerdas, Yogyakarta:2002.h.31. 